\title{
Placental transfer of NMDAR antibodies causes reversible alterations in mice
}

Anna García-Serra, MSc, Marija Radosevic, PhD, Anika Pupak, MSc, Veronica Brito, PhD, José Ríos, MSc, Esther Aguilar, BS, Estibaliz Maudes, MSc, Helena Ariño, MD, PhD, Marianna Spatola, MD, PhD, Francesco Mannara, PhD, Marta Pedreño, PhD, Bastien Joubert, MD, PhD, Silvia Ginés, PhD, Jesús Planagumà, $\mathrm{PhD}$, and Josep Dalmau, $\mathrm{MD}, \mathrm{PhD}$ *

Neurol Neuroimmunol Neuroinflamm 2021;8:e915. doi:10.1212/NXI.0000000000000915

\section{Abstract \\ Objective}

To determine whether maternofetal transfer of NMDA receptor (NMDAR) antibodies has pathogenic effects on the fetus and offspring, we developed a model of placental transfer of antibodies.

\section{Methods}

Pregnant C57BL/6J mice were administered via tail vein patients' or controls' immunoglobulin G (IgG) on days $14-16$ of gestation, when the placenta is able to transport IgG and the immature fetal blood-brain barrier is less restrictive to IgG crossing. Immunohistochemical and DiOlistic (gene gun delivery of fluorescent dye) staining, confocal microscopy, standardized developmental and behavioral tasks, and hippocampal long-term potentiation were used to determine the antibody effects.

\section{Results}

In brains of fetuses, patients' IgG, but not controls' IgG, bound to NMDAR, causing a decrease in NMDAR clusters and cortical plate thickness. No increase in neonatal mortality was observed, but offspring exposed in utero to patients' IgG had reduced levels of cell-surface and synaptic NMDAR, increased dendritic arborization, decreased density of mature (mushroomshaped) spines, microglial activation, and thinning of brain cortical layers II-IV with cellular compaction. These animals also had a delay in innate reflexes and eye opening and during follow-up showed depressive-like behavior, deficits in nest building, poor motor coordination, and impaired social-spatial memory and hippocampal plasticity. Remarkably, all these paradigms progressively improved (becoming similar to those of controls) during follow-up until adulthood.

\section{Conclusions}

In this model, placental transfer of patients' NMDAR antibodies caused severe but reversible synaptic and neurodevelopmental alterations. Reversible antibody effects may contribute to the infrequent and limited number of complications described in children of patients who develop anti-NMDAR encephalitis during pregnancy.

\author{
Correspondence \\ Dr. Dalmau \\ jdalmau@clinic.cat
}




\section{Glossary}

BBB = blood-brain barrier; CBA = cell-based assay; fEPSP = field excitatory postsynaptic potential; GEE = generalized estimated equation; GLM = generalized linear model; IgG = immunoglobulin G; LTP = long-term potentiation; NMDAR = NMDA receptor; NMDAR-ab = NMDAR antibody; NOL = novel object location; PD = postnatal day; PPI = prepulse inhibition; PSD95 = postsynaptic density protein 95 .

Anti-NMDA receptor (NMDAR) encephalitis is a neuronal antibody-mediated disease that associates with prominent neurologic and psychiatric symptoms. ${ }^{1}$ Most clinical series show that $60 \%-80 \%$ of patients are women of childbearing age $^{2-4}$ who sometimes develop the encephalitis during pregnancy. ${ }^{5,6}$ In addition to the obstetric complications that can arise from the severity of the disease, ${ }^{5-7}$ there is the concern that patient's antibodies can reach the fetal brain and cause synaptic and neurodevelopmental alterations. This concern is supported by the demonstration of the pathogenicity of the antibodies in cultured neurons ${ }^{8-10}$ and in a mouse model of cerebroventricular transfer of patients' antibodies. ${ }^{11}$ Moreover, peritoneal injection of a human NMDAR monoclonal antibody to pregnant mice resulted in high neonatal mortality and long-lasting irreversible neurodevelopmental deficits in the offspring. ${ }^{12}$

Therefore, considering the severity of patients' symptoms, pathogenicity of the antibodies, and the fact that NMDAR signaling regulates neuronal maturation, ${ }^{13}$ migration, ${ }^{14}$ and synaptogenesis, ${ }^{15}$ one would expect severe abnormalities in the offspring of patients with anti-NMDAR encephalitis. However, the clinical experience is markedly different; other than a few exceptional cases, ${ }^{16}$ most reports indicate that the offspring of these patients appear to have good outcomes. ${ }^{6}$ Indeed, among the limited number of problems reported in the babies, most are described as transient ${ }^{17}$ or attributed to medications. ${ }^{6}$ These discrepancies led us to investigate in a model of maternofetal transfer of patients' immunoglobulin $\mathrm{G}$ ( $\operatorname{IgG})$ antibodies, the effects on synaptic NMDAR, dendritic complexity, cortical development, and microglial activation in fetal and postnatal brains. We also determined whether mice exposed in utero to patients' IgG had impairment of memory, behavior, and hippocampal long-term plasticity and whether the antibody effects persisted or resolved from newborn to adulthood stages.

\section{Methods}

Most of the methods and techniques used here have been previously reported ${ }^{11,18}$ and are described in appendix e-1 (links.lww.com/NXI/A341).

\section{Human serum samples, IgG purification, and immunoabsorption}

IgG was isolated by ammonium sulfate precipitation from serum of 7 patients with anti-NMDAR encephalitis and 7 healthy blood donors. All patients with anti-NMDAR encephalitis were women (median age 20 years, range 16-26 years) with anti-NMDAR encephalitis. The presence of NMDAR antibodies (NMDAR-abs) was determined with rat brain immunohistochemistry and a cell-based assay (CBA). ${ }^{1}$ To rule out the presence of other antibodies, pooled IgG from patients was immunoabsorbed with HEK293T cells expressing GluN1/2B, and the reactivity determined with brain immunohistochemistry, CBA of GluN1/2B, and live neurons, showing with all 3 techniques abrogation of reactivity. ${ }^{10,18} \mathrm{We}$ confirmed that immunoabsorbed patients' IgG no longer decreased the levels of NMDARs after 12-hour incubation, as reported. $^{19}$

\section{Animals, infusion of IgG, tissue processing, and determination of antibodies in blood from pregnant mice and fetuses}

Animal care and processing of brain of fetuses and offspring were performed as reported. ${ }^{11}$ Overall, 54 pregnant C57BL/ $6 \mathrm{~J} \mathrm{mice,} 165$ fetuses, and 187 pups were used for behavioral, electrophysiologic, morphologic, and synaptic brain studies.

Pooled IgG $(800 \mu \mathrm{g})$ from patients or controls was injected via tail vein to pregnant mice on days 14,15 , and 16 (E14, E15, and E16) of gestation (figure 1A). These experiments were planned according to the window of time in which the neonatal receptor $(\mathrm{FcRn})$, which allows IgG transplacental transfer, is expressed in placental tissue, and the immature fetal blood-brain barrier (BBB) does not restrict the crossing of IgG (by day E16, the BBB becomes more restrictive). ${ }^{20}$ The presence of human NMDAR-abs in blood from pregnant mice and fetuses was demonstrated with immunolabeling of live rat hippocampal neurons in culture and conventional CBA. ${ }^{1}$ Antibody titers were obtained by serial sample dilution using CBA.

\section{Determination of human IgG, NMDAR clusters, and cortical plate thickness in fetal brain tissue} To determine whether human NMDAR-abs injected to pregnant mice reached the brain of fetuses, 5 - $\mu \mathrm{m}$-thick fetal brain sections were immunostained for human IgG using Alexa Fluor 488 goat anti-human IgG, as above. Quantification of fluorescence intensity was performed using the public domain Fiji ImageJ software (fiji.sc/Fiji). ${ }^{8}$ Confirmation that patients' IgG was bound to NMDAR was done by immunoprecipitation. ${ }^{18}$

The effects of patients' antibodies on total cell-surface and synaptic NMDAR clusters and postsynaptic density protein 95 (PSD95) were examined using immunohistochemistry 


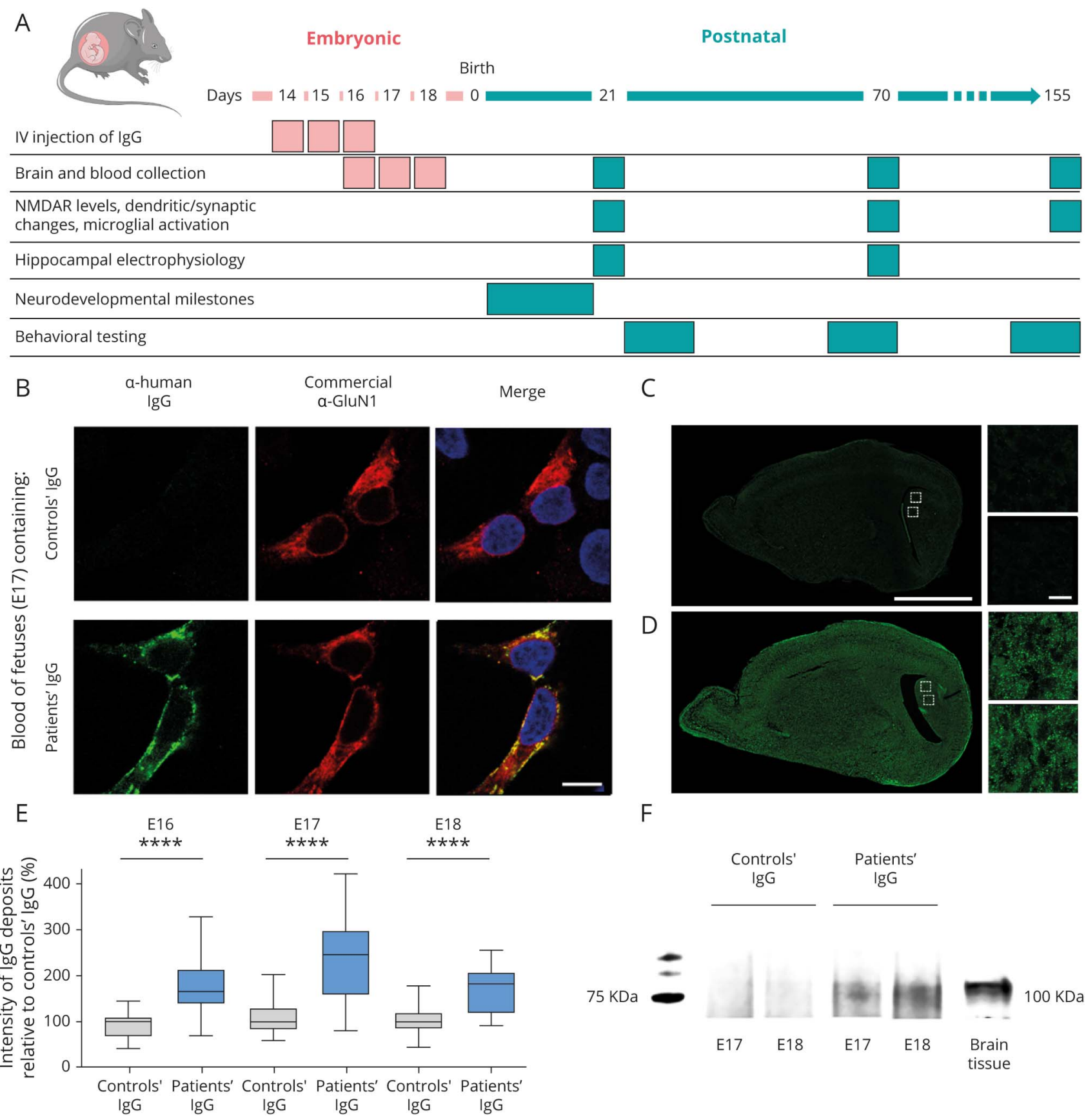

(A) Diagram of the experimental design. IV injection of pooled IgG was performed on gestational days E14, E15, and E16. Brain and blood samples from the fetus or offspring were collected on E16, E17, and E18 and PD 21, PD 70, and PD 155; blood samples of pregnant mice were collected on E16-E18. Brain tissue studies were performed on the same time points and electrophysiology on PD 21 and PD 70. Newborns were assessed daily for neurodevelopmental milestones from birth until PD 21. After breastfeeding withdrawal, mice underwent a battery of behavioral tests at age 1, 2, and 4 months. Gestational period is marked in pink and postnatal period in green. (B) Representative images of HEK293T cells expressing GluN1/2B immunolabeled with human IgG contained in serum of fetuses (E17) exposed to controls' or patients' IgG. Scale bar = $10 \mu \mathrm{m}$. (C and D) Representative human IgG immunolabeling in E17 fetal brain sections of animals exposed in utero to controls' (C) or patients' (D) IgG; the 2 insets (small squares in C and D, developing hippocampus) are shown enlarged on the right of each panel. Scale bar whole brain $=100 \mu \mathrm{m}$, insets $=10 \mu \mathrm{m}$. (E) Quantification of human IgG immunofluorescence intensity in the developing hippocampus of fetal brains obtained on gestational days E16-E18 exposed to controls' IgG or patients' IgG. Controls' IgG, E16, $n=5 ; \mathrm{E} 17, \mathrm{n}=13 ; \mathrm{E} 18, \mathrm{n}=8$; patients' IgG, E16, n = 9; E17, $n=16 ; \mathrm{E} 18, \mathrm{n}=8$. Median intensity of IgG immunofluorescence in brain of mice exposed to controls' IgG was defined as $100 \%$. Data presented in box plots show the median, 25th, and 75th percentiles; whiskers indicate minimum and maximum. Significance of treatment effect was assessed by the Mann-Whitney $U$ test. ${ }^{* * *} p<0.0001$. (F) Immunoprecipitated NMDAR-bound IgG from E17 and E18 brains of fetuses exposed in utero to controls' or patients' IgG. Lane brain tissue corresponds to homogenate of mouse brain used here as control. The band at $\sim 100 \mathrm{KDa}$ corresponds to the GluN1 subunit of the NMDAR. Each lane corresponds to the immunoprecipitation of the brains from 4 fetuses, per each indicated condition. IgG = immunoglobulin G; NMDAR = NMDA receptor; $\mathrm{PD}=$ postnatal day.

and confocal microscopy. ${ }^{11}$ The thickness of the cortical plate was measured using 4', 6-diamidino-2-phenylindole (DAPI)- stained fetal brain sections and quantified using Fiji ImageJ software. 
Determination of human IgG, NMDAR clusters, synaptic density, cortical layer thickness, and microglial activation in offspring

The presence of human IgG in the brain of offspring and the density of NMDAR were examined as indicated for fetal brains (time points shown in figure 1A). NMDAR clusters were quantified from a total of 15 images acquired from CA1, CA3, and dentate gyrus of the hippocampus ( 5 different areas per region).

The density of glutamatergic synapses was assessed with immunohistochemistry using presynaptic (Bassoon) and postsynaptic (Homer1) markers and the corresponding secondary antibodies (appendix e-1, links.lww.com/NXI/A341).

Cortical layer thickness was measured in sections of brains immunostained with specific cortical layer markers including a monoclonal mouse anti-CUTL1 for layers II-IV, and a polyclonal sheep anti-FoxP2 for layer VI, followed by the appropriate secondary antibodies. The layers' thickness was quantified using Fiji ImageJ software. Cell density in CUTL1labeled layers was measured on brain sections using DAPI staining with spots algorithm in Imaris software.

Microglial activation was assessed in brain sections using a monoclonal rat antibody against CD68 (pan-macrophage) and a polyclonal rabbit antibody against Iba-1 (activated microglia). The CD68- or Iba-1-stained surface density was quantified using Imaris software.

\section{Dendritic complexity and spine morphology analysis}

These studies were performed using DiOlistic (gene gun delivery of fluorescent dye) staining and confocal microscopy (appendix e-1, links.lww.com/NXI/A341). Dendritic complexity was examined with Sholl analysis in cortical and CA1 hippocampal pyramidal neurons. ${ }^{21}$ Spine morphology was examined in DiI-labeled segments of apical secondary dendrites of cortical and CA1 pyramidal neurons. Quantification of mushroom-shaped dendritic spines was performed with the spine classification algorithm (Imaris software).

\section{Field potential recordings, hippocampal long- term potentiation, and paired- pulse facilitation}

Acute sections of the hippocampus of the offspring were used to determine long-term plasticity by the classical paradigm of stimulation at the Schaffer collateral pathway and recording the field potentials at CA1 synapses. ${ }^{19}$

\section{Neurobehavioral assessment in postnatal and adult stages}

From birth to weaning (defined as breastfeeding withdrawal on postnatal day [PD] 21), mice were assessed daily for achievement of developmental milestones using a modified Fox battery, similar to that previously reported. ${ }^{22}$ From weaning to adulthood (155 days), subsets of mice underwent a comprehensive battery of memory and behavioral tests (appendix e-1, links.lww.com/NXI/A341, and figure e-1, links.lww.com/NXI/A342).

\section{Statistical analysis}

Comparison of human IgG intensity, confocal densities of NMDAR, PSD95, Homer1, Bassoon, Iba-1, CD68, and mushroom-shaped spines between mice exposed to patients' IgG vs controls' IgG was performed with the MannWhitney $U$ test as non-normally distributed parameters. Comparison of cortical plate thickness, cortical layers IIIV and VI, cortical cell density, and electrophysiologic field excitatory postsynaptic potential (fEPSP) slope changes between the 2 experimental groups was performed using independent sample $t$ tests. Sholl analysis data were analyzed with a generalized linear model (GLM) for global and time point effects. For behavioral paradigms, longitudinal analyses were performed by generalized estimated equations (GEEs) using an $\mathrm{AR}(1)$ matrix to account for intraindividual correlations. All models include litter size, group, and group by time as fixed factors. Time to rooting, ear detachment, auditory startle, and eye opening were analyzed with the Mann-Whitney $U$ test. All experiments were assessed for outliers with the ROUT method applying $Q=1 \%$. In all analyses, we used a 2-sided type I error of $5 \%$. All tests were performed using GraphPad Prism (version 8; GraphPad Inc., San Diego, CA) or SPSS (version 25; IBM Corp., Armonk, NY) for GLM and GEE models. Mean values or estimated mean values (body weight, righting reflex, and negative geotaxis for the GEE model) were presented with \pm SEM.

\section{Ethical approval}

Written informed consent was obtained from all patients; the study was approved by the local institutional review board at Hospital Clínic, Barcelona (HCB/2018/0192). Animal studies were approved by the Ethical Committee of the University of Barcelona (2010/63/UE) and Spanish (RD 53/2013) regulations.

\section{Data availability}

Data supporting these findings are available on reasonable request.

\section{Results}

\section{Presence of human NMDAR-abs in serum of pregnant mice and fetuses}

Serum samples collected on E16, E17, and E18 from pregnant mice and fetuses exposed to patients' IgG, but not those exposed to controls' IgG, showed human IgG binding to cell surface of live hippocampal neuronal cultures and HEK293T cells expressing GluN1/GluN2B (figure 1B). The human NMDAR antibody titer (obtained by serial dilution of samples in CBA) was 1:160-1:320 in pregnant mice and 1: $80-1: 160$ in fetuses (data not shown). 
Patients' IgG reach fetal brain, causing a reduction of synaptic NMDAR and thinning of the cortical plate

On days E16-18, fetuses exposed to patients' IgG showed increased human IgG fluorescence in the developing hippocampus compared with those exposed to controls' IgG (figure 1, C-E). Immunoprecipitation experiments confirmed the presence of NMDAR bound to IgG in the brain precipitate (figure 1F). Analysis of the density of NMDAR clusters showed that fetuses harboring patients' IgG had a significant decrease in cluster density of total cell-surface and synaptic NMDARs (figure 2, A and D). The cortical plate of these fetuses was also thinner on E17 and E18 compared with that of controls (figure 2, G and J).

\section{Offspring exposed in utero to patients' IgG} have decreased NMDAR and synaptic density, thinning of cortical layers, and

\section{microglial activation}

On PD 21 and 70, mice exposed in utero to patients' IgG no longer had significant brain deposits of IgG (not shown). Despite this, the reduction of total cell-surface NMDAR clusters persisted until day 70 (figure 2, B and C) with subsequent normalization, so that by day 155 , the levels were similar to those of controls (not shown). In contrast, the levels of synaptic NMDAR normalized faster; they were decreased on day 21 (figure $2 \mathrm{E}$ ), but were normal on days 70 and 155 (figure 2F, not shown). PSD95 cluster density was not affected at any time point (data not shown).

Mice exposed to patients' IgG, but not controls' IgG, showed thinning of cortical layers II-IV (assessed with CUTL1/FoxP2 staining) on PD 21 (figure 2, $\mathrm{H}$ and $\mathrm{K}$ ) that was no longer present on PD 70 (figure 2, I and L). This transient thinning of cortical layers II-IV was associated with an increase in cell density in these layers on PD 21 ( $p=0.0065$, data not shown).

On PD 21, the density of glutamatergic synapses (assessed by colocalization of Homer1/Bassoon clusters) was decreased in mice exposed in utero to patients' IgG (figure 3, A and B). These effects were no longer seen on day 70 (not shown).

On PD 21 and 70, there was an increase of 57\% and 53\% in activated microglia (assessed by expression of Iba-1 in somatosensory cortex) in mice exposed in utero to patients' IgG (figure 3, C and D). This difference in activated microglia was no longer present on PD 155 (not shown). No significant difference in the total number of microglial cells (assessed by expression of CD68) was noted between groups of mice at any time point examined (figure $3 \mathrm{E}$ ).

Exposure to patients' IgG causes alterations in dendritic complexity, spine density, and spine morphology in cortical and hippocampal pyramidal neurons

Dendritic arborization was assessed by Sholl analysis (figure 4, A and B). On PD 21, the Sholl analysis in cortical and hippocampal areas showed a higher dendritic arborization in mice exposed in utero to patients' IgG (figure 4, C and D, left). No differences were noted on PD 70 (figure $4, C$ and $D$, right).

The density of mushroom-shaped (mature) dendritic spines was assessed in the cerebral cortex and hippocampus using the Imaris standard parameters for dendritic spine classification (example shown in figure 4, E-G). On PD 21, the density of these spines was significantly decreased in mice exposed in utero to patients' IgG (cortex, figure $4 \mathrm{H}$, left; hippocampus, figure 4I, left). The changes were no longer seen on PD 70 (cortex, figure $4 \mathrm{H}$, right; and hippocampus, figure 4I, right).

Intrauterine exposure to patients' IgG causes a reversible impairment in hippocampal longterm potentiation formation

Assessment of fEPSPs showed that on PD 21, mice that had been exposed in utero to patients' IgG had impairment in long-term potentiation (LTP) formation compared with mice exposed in utero to controls' IgG (figure e-2, A-C, links.lww. com/NXI/A343). This change in LTP formation was no longer detected on PD 70 (figure e-2, D-F). Paired-pulse facilitation studies at 50 and 100 milliseconds of interstimuli interval (which assess presynaptic release mechanisms) were not different between groups of animals (data not shown).

\section{Neurodevelopmental delay due to in utero exposure to NMDAR-abs}

Newborn pups exposed in utero to patients' IgG showed multiple alterations including transient decrease of weight (figure 5A); longer times for proper body righting (figure 5B) and negative geotaxis (figure $5 \mathrm{C}$ ); delayed eye opening (figure 5D); and longer time in open field locomotion (not shown, $p<0.01$ ). Neonatal mortality occurred in litters of mice exposed in utero to controls' IgG (26\%) or patients' IgG (25\%), which is in line with general litter loss in laboratory mice. ${ }^{23}$ No significant differences were observed in ear detachment, tactile rooting response, and auditory startle (data not shown).

\section{Spontaneous reversal of behavioral alterations from early to mature adulthood}

At age 1 month, mice exposed in utero to patients' IgG showed a significant decrease in the novel object location (NOL) index indicating impairment in visuospatial memory (figure 5E), a higher amount of unused material for nest building (figure $5 \mathrm{~F}$ ), and a longer time of exploration of a familiar intruder mouse indicating impairment in social memory (figure 5G, trial 4). Assessment of motor coordination and balance showed that mice exposed in utero to patients' IgG had shorter times on the accelerating rotarod (figure $5 \mathrm{H}$ ). No significant differences were noted in prepulse inhibition (PPI) of acoustic startle reaction, locomotor activity, or adult body weight at age 1 month (data not shown).

At age 2 months, the alterations of NOL, nest building, and social interaction in mice that had been exposed to patients' 
Figure 2 Intrauterine exposure to patients' IgG causes a transient reduction of cell-surface NMDARs and thinning of the cortical plate and cortical layers II-IV

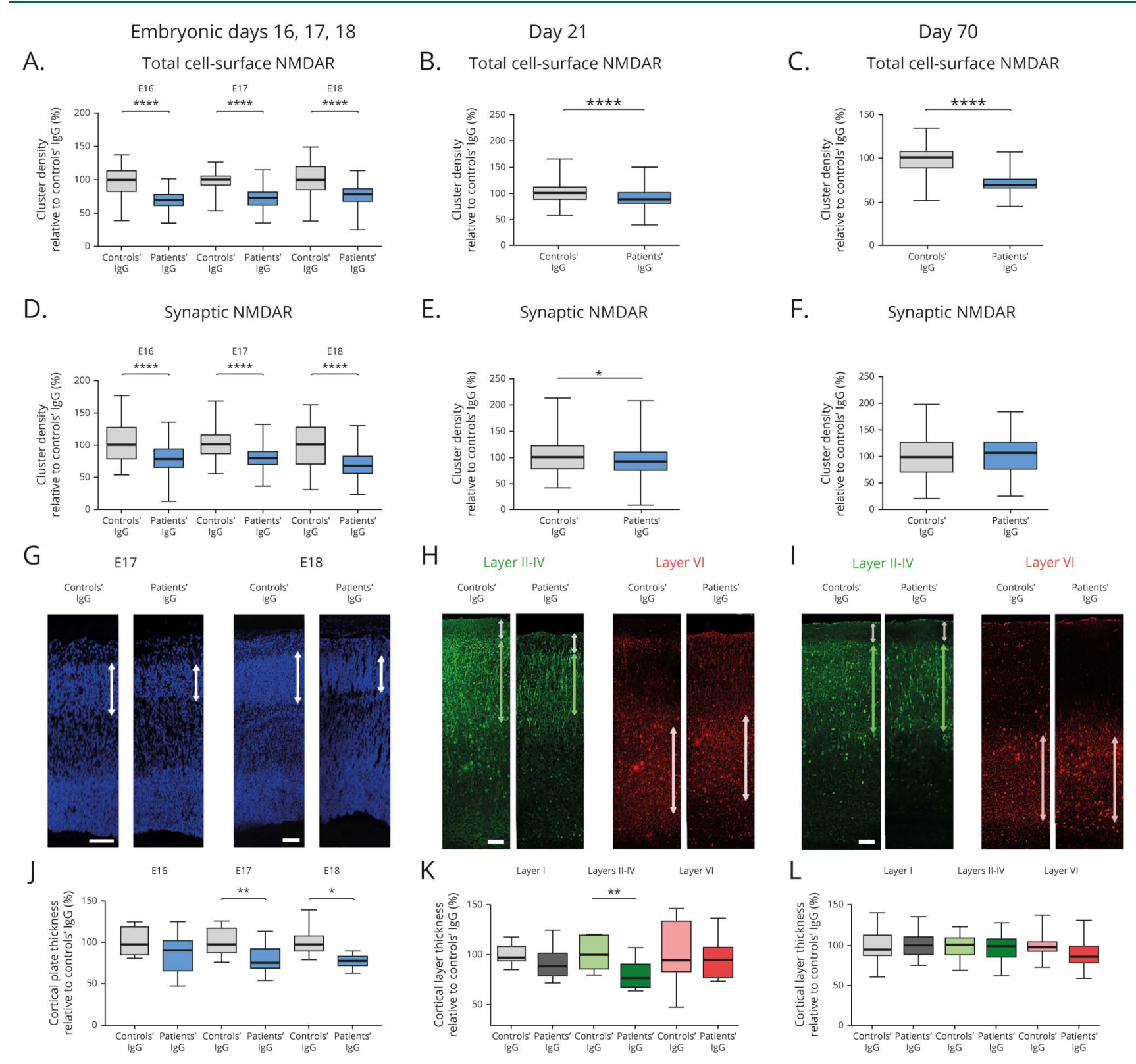

(A-F) Quantification of total cell-surface (A-C) and synaptic (D-F) NMDAR cluster density in brains obtained on gestational days E16, E17, and E18 (A and D), PD 21 ( $B$ and $E$ ), and PD 70 ( $C$ and F) from animals exposed in utero to controls' IgG or patients' IgG. Median of NMDAR clusters in mice exposed to controls' IgG was defined as 100\%. Controls' IgG, E16, $n=6 ; E 17, n=15 ; E 18, n=7 ; P D 21, n=11 ; P D 70, n=9 ; p a t i e n t s^{\prime} I g G, E 16, n=13 ; E 17, n=21 ; E 18, n=5 ; P D 21, n=14 ; P D$ $70, n=10$. (G) Representative cortical plate thickness (assessed with DAPI) in E17 and E18 brains of fetuses exposed in utero to controls' or patients' IgG. Scale bars $=100 \mu \mathrm{m}$. (H-I) Representative sections of the somatosensory cortex (H, PD 21; I, PD 70) of animals exposed in utero to controls' or patients' IgG, showing cortical layers II-IV (CUTL1 positive, green fluorescence) and cortical layer VI (FoxP2 positive, red fluorescence); arrows indicate the thickness of the indicated layers. Scale bars $=100 \mu \mathrm{m}$. (J) Quantification of cortical plate thickness in E16, E17, and E18 brains of fetuses exposed in utero to controls' IgG or patients' IgG. Controls' IgG, E16, $n=4 ; E 17, n=11 ; E 18, n=10$; patients' IgG, E16, $n=8 ; E 17, n=14 ; E 18, n=8$. (K and L) Quantification of the indicated cortical layers' thickness (K, PD 21; L, PD 70) in animals exposed to controls' IgG or patient's IgG. Controls' IgG, PD 21, $n=7 ;$ PD 70, $n=8 ; p a t i e n t s^{\prime}$ IgG, PD 21, $n=15 ;$ PD 70, $n=10$. For J-L, the mean thickness of the cortical plate or the indicated cortical layers in mice exposed in utero to controls' IgG was defined as $100 \%$. Data presented in box plots show the median, 25th, and 75th percentiles; whiskers indicate minimum and maximum. Significance of treatment effect was assessed by the MannWhitney $U$ test in A-F and independent sample $t$ test in $\mathrm{J}-\mathrm{L}$. ${ }^{\star} p<0.05,{ }^{\star} p<0.01,{ }^{*} * \star p<0.0001$. IgG $=$ immunoglobulin G; NMDAR $=\mathrm{NMDA}$ receptor; PD $=$ postnatal day.

IgG were no longer present (figure 5, I and J; social interaction not shown). PPI and locomotor activity remained unaffected at age 2 months (not shown). However, mice exposed in utero to patients' IgG showed a shorter time on the accelerating rotarod (data not shown, $p=0.0292$ ) and longer time of immobility in the tail suspension test (which assesses core helplessness) (figure 5K).

At age 4 months (adulthood), no significant difference was noted between mice exposed in utero to patients' IgG and 
Figure 3 Intrauterine exposure to patients' IgG causes a reversible decrease in synaptic density and increase in activated microglia

A.
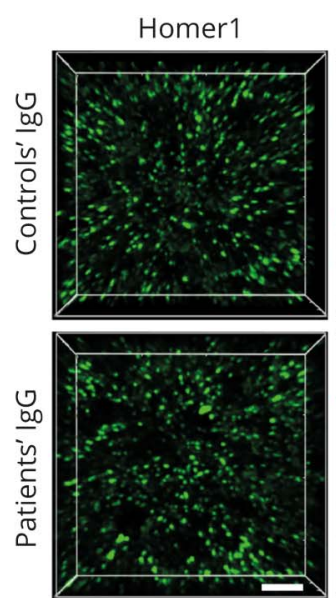

C.
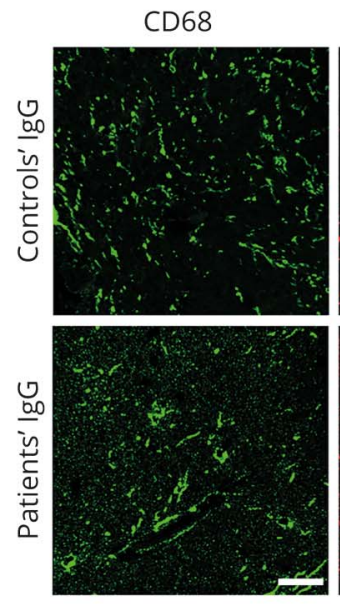

Day 21
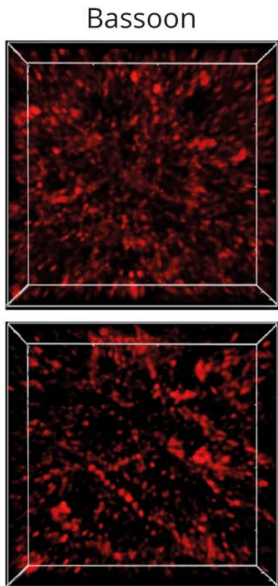

Day 21

Iba-1
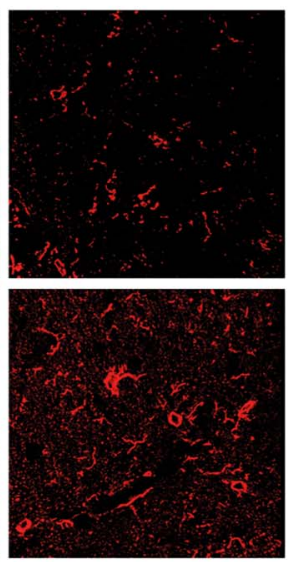

Synapse

Homer1/Bassoon

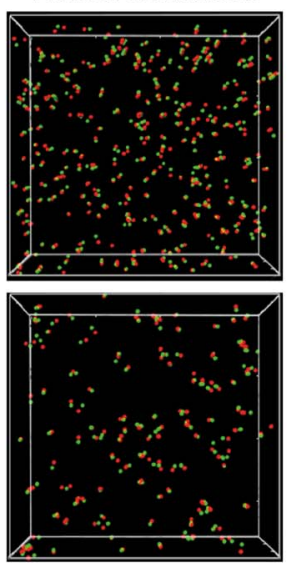

Merge
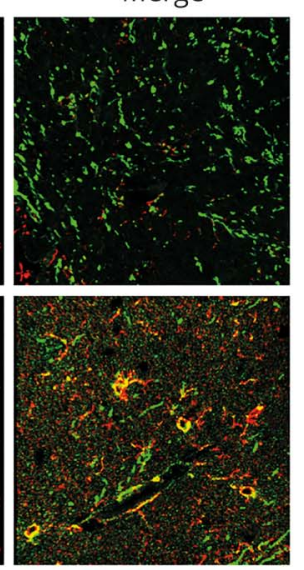

B.

Day 21

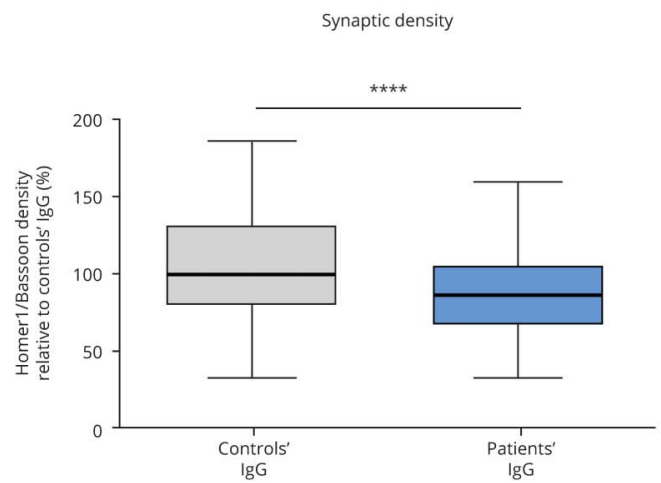

D
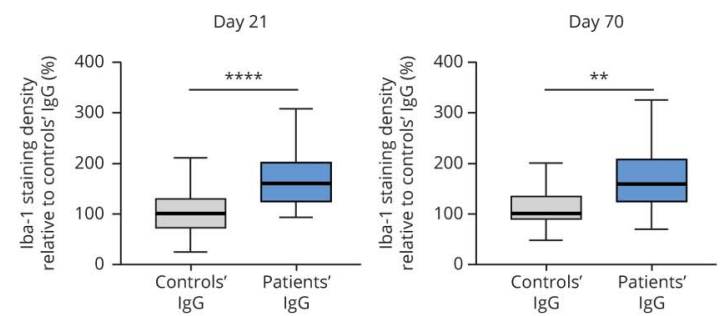

E

Day 21

Day 70

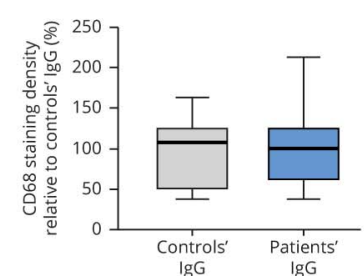

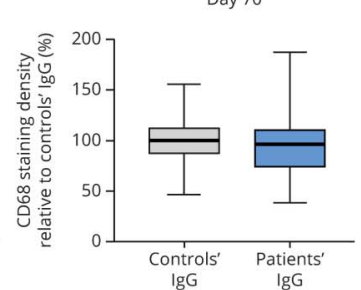

(A) Representative z-stacks of brain sections obtained on PD 21 from mice exposed in utero to controls' or patients' IgG immunostained for Homer1 and Bassoon expression. Colocalization of both markers is defined as a glutamatergic synapse. Scale bar = $2 \mu \mathrm{m}$. (B) Quantification of synaptic density (Homer1/ Bassoon colocalization) in brains obtained on PD 21 from animals exposed in utero to controls' IgG or patients' IgG. Median density of Homer1/Bassoon synapses in mice exposed in utero to controls' IgG was defined as 100\%. Controls' IgG, $n=11$; patients' IgG, $n=14$. (C) Representative CD68 (macrophage specific) and Iba-1 (activated microglia specific) immunostainings in brains obtained on PD 21 from mice exposed in utero to controls' or patients' IgG. Scale bar $=20 \mu \mathrm{m}$. (D and E) Quantification of Iba-1 (D) and CD68 (E) immunostaining in brains obtained at PD 21 and PD 70 from mice exposed to controls' IgG or patients' IgG. Median surface density of immunostaining in mice exposed in utero to controls' IgG was defined as $100 \%$. Controls' IgG, $P D 21, n=11 ; P D 70, n=$ 9; patients' IgG, PD 21, $n=14 ;$ PD 70, $n=10$. Data presented in box plots show the median, 25th, and 75th percentiles; whiskers indicate the minimum and maximum. Significance of treatment effect was assessed by the Mann-Whitney $U$ test. ** $p<0.01,{ }^{*} * \star p<0.0001$. IgG $=$ immunoglobulin G; PD = postnatal day.

those exposed to controls' IgG in any of the following tests: tail suspension (figure 5L), rotarod, locomotor activity, NOL, PPI, nest building, and social interaction (not shown).

\section{Discussion}

We show that antibodies from patients with anti-NMDAR encephalitis infused to pregnant mice reached the fetal brain, caused multiple alterations ranging from NMDAR synaptic changes to delayed neurodevelopment and behavioral deficits in the offspring, and that all these alterations progressively resolved after birth (summary in table e-1, links.lww.com/NXI/A341). As expected from previous experience with adult mice in which patients' IgG was infused in the cerebroventricular system, ${ }^{11,19}$ we observed a robust antibody-mediated decrease in NMDAR clusters in the brain of the fetuses. These effects occurred quickly (noted 2 days after injecting the antibodies to the mothers), and the observed reduction of NMDAR clusters and impairment of memory and hippocampal long-term plasticity were detectable during the first postnatal month.

In addition, hippocampal and cortical neurons from mice exposed in utero to patients' IgG showed an increase in dendritic arborization accompanied by a reduction of mature 
Figure 4 Intrauterine exposure to patients' IgG causes a transient increase in dendritic complexity and decrease in spine density

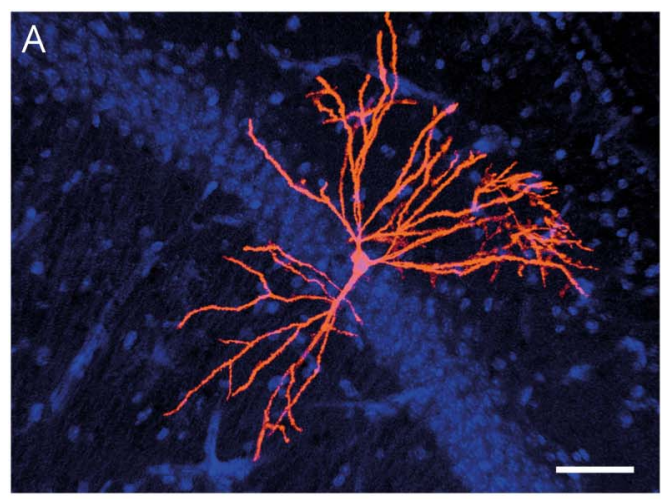

C.

Cortex

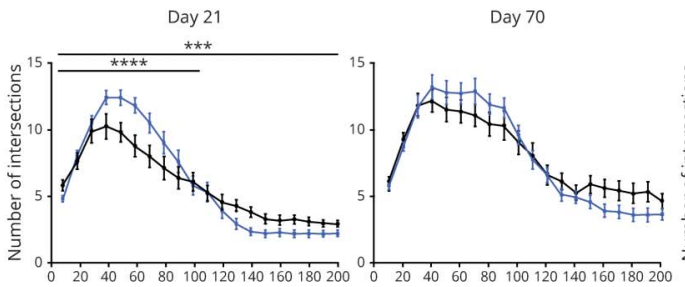

Distance from the soma $(\mu \mathrm{m})$
B

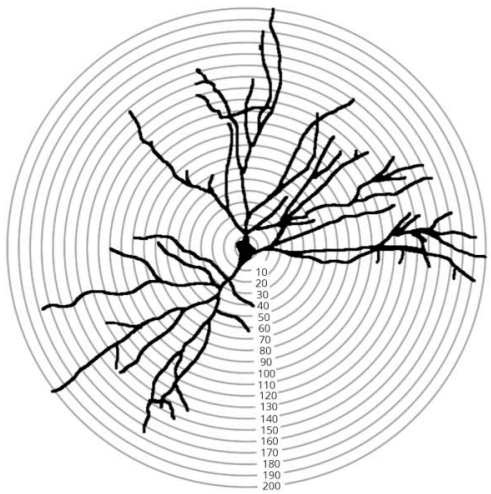

D.

Hippocampus

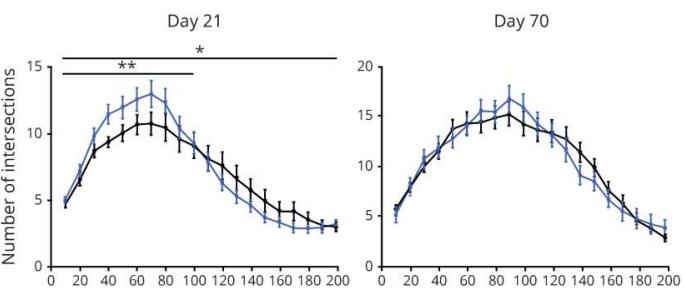

Distance from the soma $(\mu \mathrm{m})$

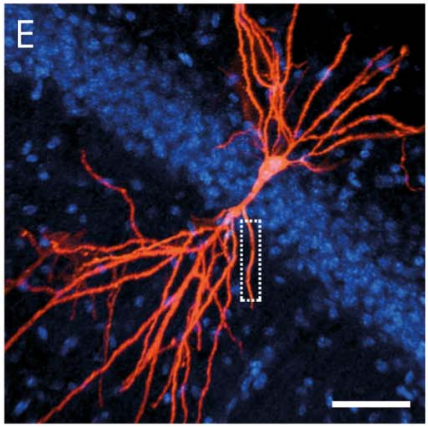

H. Cortex

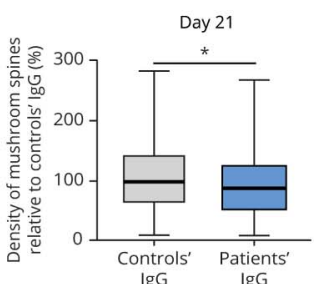

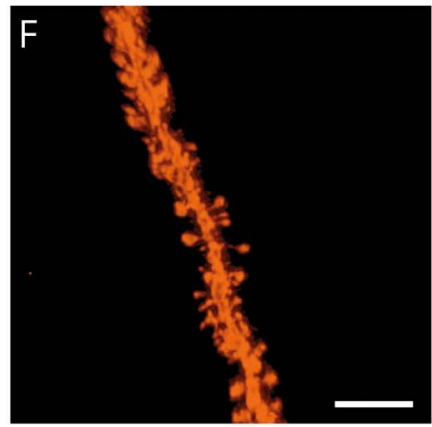

I. Hippocampus

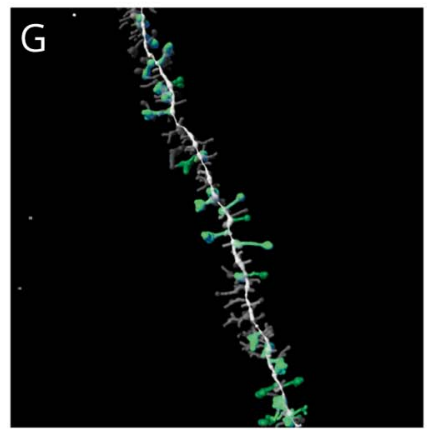

Day 70
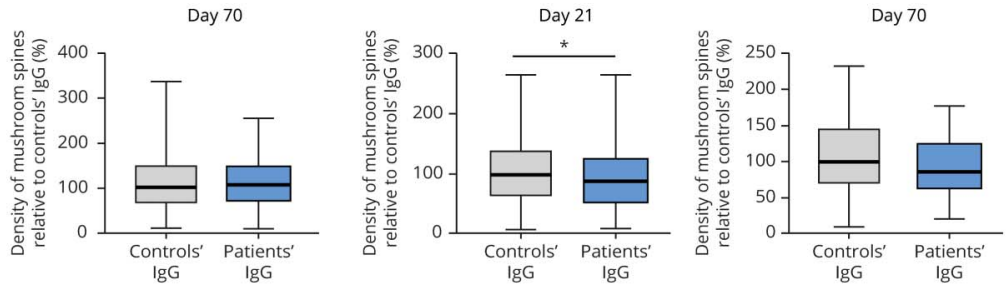

(A and B) Representative confocal image (A) and Sholl analysis (B) of a Dil-stained CA1 hippocampal pyramidal neuron showing in B the 10- $\mu$ m spaced concentric rings used for quantification of dendritic complexity. Scale bar in $A=50 \mu \mathrm{m}$. (C and D) Number of dendrite intersections according to the indicated distance to the neuronal soma in cortical and hippocampal neurons examined at PD 21 and PD 70 of mice exposed in utero to controls' (Black) or patients' (blue) IgG. Number of mice exposed in utero to controls' IgG, PD 21, n = 6; PD 70, n= 4; number of mice exposed in utero to patients' IgG, PD 21, $n=6$; PD 70, $n=$ 4. Per each animal, condition, and brain region, 4 neurons were examined. Data presented as mean \pm SEM. Significance of treatment effect was assessed by a

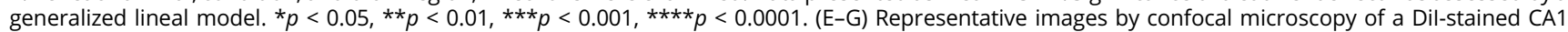
hippocampal pyramidal neuron (E) and a secondary apical dendrite (F), with morphologically classified dendritic spines (G, mushroom-shaped spines in green); Scale bar in $\mathrm{E}=50 \mu \mathrm{m}$; scale bar in $\mathrm{F}=5 \mu \mathrm{m}$. ( $\mathrm{H}$ and I) Quantification of mushroom dendritic spine density in cortical and hippocampal neurons examined at PD 21 and PD 70 in mice exposed in utero to controls' or patients' IgG. The median density of mushroom spines (number of spines/ $\mu$ m) in mice exposed to controls' IgG was defined as $100 \%$. Total number of dendrites examined/total number of mice exposed to controls' IgG: PD 21 , cortex $n=122 / 6$, hippocampus $n=120 / 6$; PD 70, cortex $n=81 / 4$, and hippocampus $n=81 / 4$. Total dendrites/mice exposed to patients' IgG: PD 21, cortex $n=141 / 6$, hippocampus $n=148 / 6$; PD 70, cortex $n=70 / 4$, and hippocampus $n=72 / 4$. Data presented in box plots show the median, 25th, and 75th percentiles; whiskers indicate minimum and maximum. Significance of treatment effect was assessed by the Mann-Whitney $U$ test in $\mathrm{H}$ and I. ${ }^{*} p<0.05$. IgG $=$ immunoglobulin G; PD $=$ postnatal day. 
Figure 5 Intrauterine exposure to patients' IgG causes transient developmental delay and behavioral alterations in offspring

Developmental assessment

Newborns

A. Weight

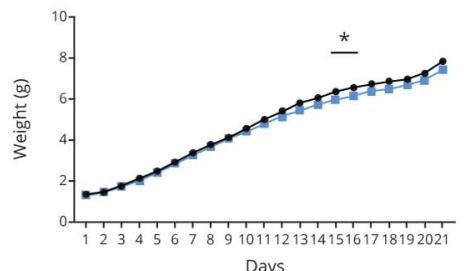

Days

Adult behavior

E. Novel object location test

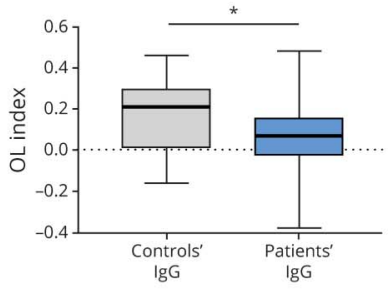

I. Novel object location test

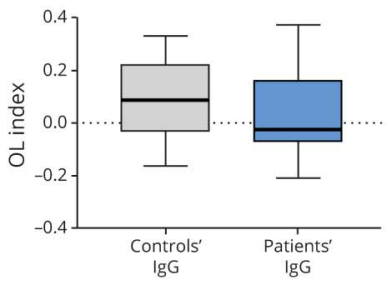

B. Surface righting reflex

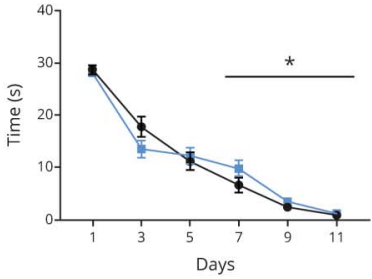

C. Negative geotaxis

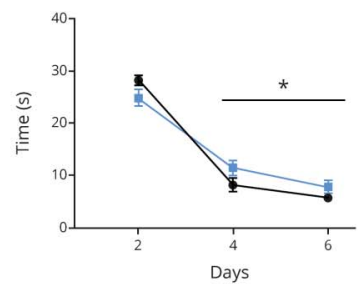

D. Eye opening

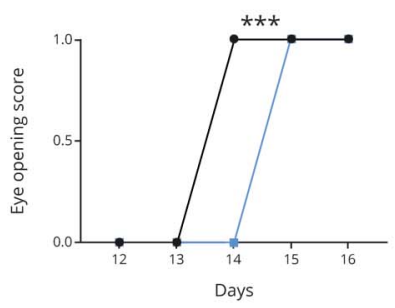

1 month

F. Nest building test

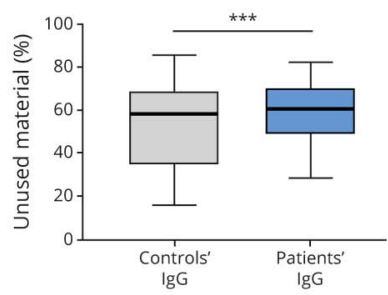

2 months

J. Nest building test

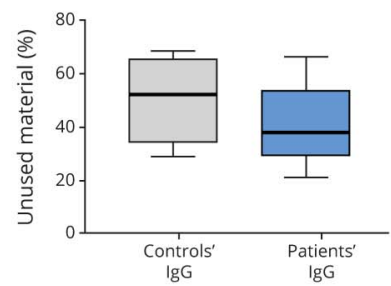

G. Social interaction test

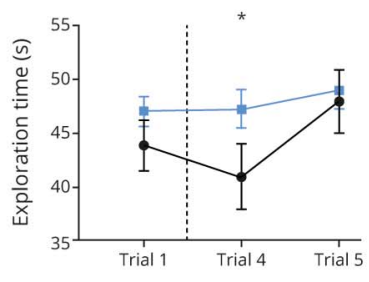

K. Tail suspension test

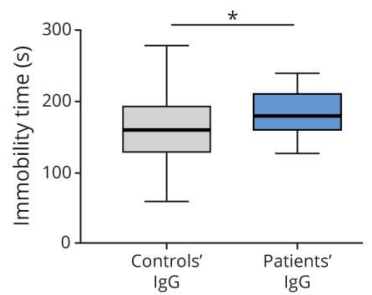

H. Rotarod test time

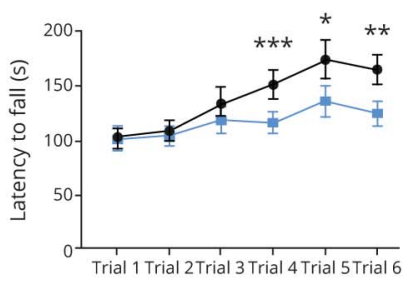

4 months

L. Tail suspension test

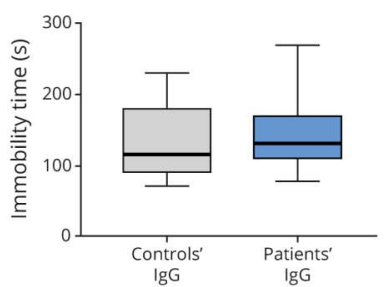

(A-D) Developmental milestone assessment (from birth to PD 21) in mice that were exposed in utero to controls' (Black) or patients' (blue) IgG including (A) body weight, (B) time needed for body righting using the surface righting reflex test (PD 1, 3, 5, 7, 9, and 11), (C) time needed for $180^{\circ}$ turning to head up position using the negative geotaxis reflex (PD 2, 4, and 6), and (D) scored eye opening (PD 12-16). Number of mice exposed in utero to controls' lgG = 36; number of mice exposed to patients' IgG $=40$. Data from A-C are represented as estimated mean \pm SEM inferred by the GEE models described in Methods and in $D$ are represented as median. Significance of treatment effect was assessed by a GEE adjusted model (A-C) and Mann-Whitney $U$ test (D). ${ }^{*} p<0.05, * \star * p<$ 0.001. (E-L) Battery of behavioral tests performed at the indicated time points including novel object location index ( $\mathrm{E}, 1$ month; $\mathrm{I}, 2$ months), nest building test (F, 1 month; J, 2 months), social interaction test (G, 1 month), rotarod test ( $\mathrm{H}, 1$ month), and tail suspension test (K, 2 months; L, 4 months). For E-I and K, number of mice exposed to controls' $\lg G=18$ and mice exposed to patients' $\lg G=18$. For $\mathrm{J}$ and $\mathrm{L}$, number of mice exposed to controls' $\mid \mathrm{g} G=8$ and mice exposed to patients' IgG = 9. Data from panels $E, F$, and I-L are represented as box plots with median, 25th, and 75 th percentiles; whiskers indicate minimum and maximum values; data from $\mathrm{G}$ and $\mathrm{H}$ are represented as mean $\pm \mathrm{SEM}$. For all behavioral tests, significance of treatment effect was assessed by $\mathrm{GEE}$. ${ }^{*} p<$ $0.05, * \star p<0.01, * \star \star p<0.001$. GEE = generalized estimated equation; IgG = immunoglobulin G; PD = postnatal day.

(mushroom-shaped) dendritic spines and synaptic density. These alterations have not been reported in previous models of immunodepletion of NMDAR and likely contributed to the impairment of hippocampal LTP. The effect of NMDAR hypofunction on dendritic arborization and the morphology of the spines are not well understood. In a cortex-specific GluN1 knockout model, the cortical neurons in layer IV elaborated exuberant dendritic specializations ${ }^{24}$; however, in a study using MK801 (an NMDAR antagonist) during early postnatal development, there was a transient decrease in dendritic arborization in hippocampal pyramidal neurons that reversed when MK801 was discontinued. ${ }^{25}$ Our findings resemble those of the cortex-specific GluN1 knockout, although in our immune model, the alterations were reversible.

We believe that the increased dendritic arborization observed in animals exposed in utero to patients' IgG was likely caused by the reduction of NMDAR levels along with microglial activation. Any perinatal immune challenge such as the binding of antibodies to NMDAR in the fetal brain can result in microglial activation ${ }^{26}$ and consequently affect microgliamediated synaptic pruning. This normal microglial function is also triggered by neural activity in the developing brain. ${ }^{27,28}$ For example, impaired microglia-neuron interactions in 
CX3CR1-deficient mice showed delayed synaptic functional maturation $^{29}$ and immature and redundant connectivity, the latter attributed to reduced synaptic pruning. ${ }^{30}$ These alterations spontaneously reverted by PD $30-40,{ }^{29,30}$ similar to our findings.

In our model, the brain of fetuses and offspring exposed in utero to patients' IgG had a reduction in the thickness of the cortical plate and cortical layers II-IV. In mice, glutamate serves as a chemoattractant for neurons in the developing cortex, signaling cells to migrate into the cortical plate through receptor activation. ${ }^{14}$ Studies with NMDAR antagonists (MK801 or APV) have shown that they block neuronal cell migration from the ventricular zone into the cortical plate, delaying neuronal migration to the upper cortical layers (II-III). ${ }^{14,31}$ In our immune-mediated model, the transient decrease in thickness of cortical layers II-IV was associated with an increase in cell density in the upper cortical layers that likely contributed to the restoration of the cortical layer thickness after PD 21. These findings are somewhat similar to those obtained in models of genetic disruption of other proteins and receptors where the decrease in cortical thickness is reversible and associates with an increase in cell density in the upper cortical layers. ${ }^{32,33}$ For example, loss of MeCP2 in the Rett syndrome model results in a reduction in thickness of somatosensory cortical layers II-III and VI, with a total rescue of thickness after treatment with mirtazapine during PD $28-42 .{ }^{33}$ In another model based on a constitutive reduction in central serotonin (VMAT2 $2^{\text {sert-cre }}$ mice), the total cortical thickness reduction at PD 7 spontaneously recovered by PD $14 .^{32}$ Like this model, our anti-NMDAR model associates with a temporary delay in the development of the upper cortical layers along with increased compaction of these layers.

Preceding the indicated memory deficit, the newborn pups exposed in utero to patients' IgG showed impaired innate reflexes and developmental delay. Similar impairment of native reflexes and developmental delay have been reported in GluN1 gene-manipulated mice, ${ }^{34}$ and newborn rats treated with a competitive NMDAR antagonist. ${ }^{35}$

A previous model of transplacental transfer of a humanderived NMDAR monoclonal antibody showed high neonatal mortality (27\%), impairment of native reflexes, and longlasting neuropathologic alterations without evidence of reversibility. ${ }^{12}$ In contrast, we did not observe increased neonatal mortality, and the symptoms and developmental alterations spontaneously improved. Moreover, although the monoclonal antibody model did not assess dendritic arborization, spine density, cortical development, and number of cell surface and synaptic NMDAR clusters, we found that patients' IgG antibodies robustly altered all these paradigms, along with a dramatic decrease in NMDAR clusters and hippocampal LTP. Thus, the reversibility of these alterations and associated symptoms cannot be attributed to a milder phenotype. The reasons for the discrepancies between our model, in which serum NMDAR-abs representative of several patients were used, and the model in which a human monoclonal NMDAR-ab was used are unclear. It is likely that the monoclonal antibody model, lacking the repertoire NMDARabs of patients, is less representative of the disease. Nevertheless, the outcome of newborns from pregnant patients with anti-NMDAR encephalitis ${ }^{6}$ is remarkably different from that obtained with the mouse monoclonal antibody model. ${ }^{12}$

Our study does not allow generalization of the notion that anti-NMDAR encephalitis during pregnancy does not represent a risk for serious effects in the offspring. For example, our model does not associate with encephalitis of the mothers, which in our experience ${ }^{6}$ is the most important risk factor for obstetric complications and potential brain damage of the newborns. However, the low frequency of antibody-mediated complications in newborns of patients with anti-NMDAR encephalitis is puzzling and may also be related to the timings of IgG placental transfer and BBB restriction properties for IgG crossing into the brain. In humans, placental transfer of maternal antibodies starts at 12-13 weeks of pregnancy ${ }^{36-38}$ that is approximately the same time the $\mathrm{BBB}$ of the fetus starts to become more restrictive to the passage of albumin (and likely Igs) to the brain. ${ }^{39}$ It is unknown whether this time window and the efficiency of the fetal BBB are affected by the presence of maternal encephalitis or systemic inflammation. Future studies with pregnant patients who develop antiNMDAR encephalitis and close follow-up of the babies are needed to determine the frequency of deficits (if present, mostly overlooked until now) and the timing of improvement. Keeping these limitations in mind, the current model suggests that reversibility of some of the antibody-mediated alterations can potentially occur. Moreover, the model can be manipulated to assess the effects of systemic inflammation and provides also the possibility to determine whether inhibitors of FcRn have potential utility in preventing the potential neonatal abnormalities reported here.

\section{Acknowledgment}

The authors thank Dr. Myrna R. Rosenfeld (IDIBAPS, University of Barcelona) for critical review of the manuscript and useful suggestions and Mercedes Alba, Eva Caballero, and Araceli Mellado (IDIBAPS, Hospital Clínic, University of Barcelona) for their technical support.

\section{Study funding}

This study was funded by Plan Nacional de I+D+I and cofinanced by the Instituto de Salud Carlos III (ISCIII)Subdirección General de Evaluación y Fomento de la Investigación Sanitaria and the Fondo Europeo de Desarrollo Regional (ISCIII-FEDER; 17/00234); Project Integrative of Excellence (PIE 16/00014); Centro de Investigación Biomédica en Red de Enfermedades Raras (CIBERER; \#CB15/ 00010); "La Caixa” Foundation (ID 100010434, under the agreement LCF/PR/HR17/52150001); The Safra Foundation (J.D.), and Fundació CELLEX (J.D.); Centres de Recerca de Catalunya (CERCA) program by La Generalitat 
de Catalunya (J.R.); Pla Estratègic de Recerca i Innovació en Salut (PERIS, SLT002/16/00346, J.P.); Ministerio de Economia y Competitividad (RTI2018-094374-B-I00, S.G.); Basque Government Doctoral Fellowship Program (PRE 2019_1_0255; E.M.); and Agència de Gestió d'Ajuts Universitaris i de Recerca (FI-AGAUR) grant program by La Generalitat de Catalunya (2018FI_B_00487 A.P.; 2019FI_ B1 00212, A.G.-S.).

\section{Disclosure}

A. García-Serra, M. Radosevic, A. Pupak, V. Brito, J. Ríos, E. Aguilar, E. Maudes, H. Ariño, M. Spatola, F. Mannara, M. Pedreño, B. Joubert, S. Ginés, and J. Planagumà report no disclosures. J. Dalmau receives royalties from Athena Diagnostics for the use of $\mathrm{Ma} 2$ as an autoantibody test and from Euroimmun for the use of NMDA, GABAB receptor, GABAA receptor, DPPX and IgLON5 as autoantibody tests. Go to Neurology.org/NN for full disclosures.

\section{Publication history}

Received by Neurology: Neuroimmunology \& Neuroinflammation July 13, 2020. Accepted in final form August 26, 2020.

Appendix Authors

\begin{tabular}{|c|c|c|}
\hline Name & Location & Contribution \\
\hline $\begin{array}{l}\text { Anna } \\
\text { García- } \\
\text { Serra, MSc }\end{array}$ & $\begin{array}{l}\text { IDIBAPS, Hospital Clínic, } \\
\text { Universitat de Barcelona, } \\
\text { Spain }\end{array}$ & $\begin{array}{l}\text { Major role in the } \\
\text { acquisition of data; } \\
\text { analyzed the data; and } \\
\text { drafted the manuscript for } \\
\text { intellectual content }\end{array}$ \\
\hline $\begin{array}{l}\text { Marija } \\
\text { Radosevic, } \\
\text { PhD }\end{array}$ & $\begin{array}{l}\text { IDIBAPS, Hospital Clínic, } \\
\text { Universitat de Barcelona, } \\
\text { Spain }\end{array}$ & $\begin{array}{l}\text { Major role in the } \\
\text { acquisition of data; } \\
\text { analyzed the data; and } \\
\text { revised the manuscript for } \\
\text { intellectual content }\end{array}$ \\
\hline $\begin{array}{l}\text { Anika } \\
\text { Pupak, MSc }\end{array}$ & $\begin{array}{l}\text { IDIBAPS, Hospital Clínic, } \\
\text { and Institut de } \\
\text { Neurociències, Universitat } \\
\text { de Barcelona; and } \\
\text { CIBERNED, Madrid, Spain }\end{array}$ & $\begin{array}{l}\text { Major role in the } \\
\text { acquisition of data and } \\
\text { revised the manuscript for } \\
\text { intellectual content }\end{array}$ \\
\hline $\begin{array}{l}\text { Veronica } \\
\text { Brito, PhD }\end{array}$ & $\begin{array}{l}\text { IDIBAPS, Hospital Clínic, } \\
\text { and Institut de } \\
\text { Neurociències, Universitat } \\
\text { de Barcelona; and } \\
\text { CIBERNED, Madrid, Spain }\end{array}$ & $\begin{array}{l}\text { Major role in the } \\
\text { acquisition of data and } \\
\text { revised the manuscript for } \\
\text { intellectual content }\end{array}$ \\
\hline $\begin{array}{l}\text { José Ríos, } \\
\text { MSc }\end{array}$ & $\begin{array}{l}\text { Medical Statistics Core } \\
\text { Facility, IDIBAPS and } \\
\text { Hospital Clínic, Barcelona; } \\
\text { and Biostatistics Unit, } \\
\text { Faculty of Medicine, } \\
\text { Universitat Autònoma de } \\
\text { Barcelona, Spain }\end{array}$ & $\begin{array}{l}\text { Analyzed the data and } \\
\text { revised the manuscript for } \\
\text { intellectual content }\end{array}$ \\
\hline $\begin{array}{l}\text { Esther } \\
\text { Aguilar, BS }\end{array}$ & $\begin{array}{l}\text { IDIBAPS, Hospital Clínic, } \\
\text { Universitat de Barcelona, } \\
\text { Spain }\end{array}$ & $\begin{array}{l}\text { Major role in the } \\
\text { acquisition of data and } \\
\text { revised the manuscript for } \\
\text { intellectual content }\end{array}$ \\
\hline $\begin{array}{l}\text { Estibaliz } \\
\text { Maudes, } \\
\text { MSc }\end{array}$ & $\begin{array}{l}\text { IDIBAPS, Hospital Clínic, } \\
\text { Universitat de Barcelona, } \\
\text { Spain }\end{array}$ & $\begin{array}{l}\text { Major role in the } \\
\text { acquisition of data and } \\
\text { revised the manuscript for } \\
\text { intellectual content }\end{array}$ \\
\hline
\end{tabular}

Appendix (continued)

\begin{tabular}{lll}
\hline Name & Location & Contribution \\
\hline $\begin{array}{l}\text { Helena } \\
\text { Ariño, MD, } \\
\text { PhD }\end{array}$ & $\begin{array}{l}\text { IDIBAPS, Hospital Clínic, } \\
\text { Spain }\end{array}$ & $\begin{array}{l}\text { Performed IV } \\
\text { administrations and } \\
\text { revised the manuscript for } \\
\text { intellectual content }\end{array}$ \\
\hline $\begin{array}{l}\text { Marianna } \\
\text { Spatola, MD, } \\
\text { PhD }\end{array}$ & $\begin{array}{l}\text { IDIBAPS, Hospital Clínic, } \\
\text { Spain }\end{array}$ & $\begin{array}{l}\text { Performed } \\
\text { immunoprecipitation } \\
\text { technique and revised the } \\
\text { manuscript for intellectual }\end{array}$ \\
& & $\begin{array}{l}\text { content } \\
\text { conar }\end{array}$ \\
\hline
\end{tabular}

\begin{tabular}{|c|c|c|}
\hline $\begin{array}{l}\text { Francesco } \\
\text { Mannara, } \\
\text { PhD }\end{array}$ & $\begin{array}{l}\text { IDIBAPS, Hospital Clínic, } \\
\text { Universitat de Barcelona, } \\
\text { Spain }\end{array}$ & $\begin{array}{l}\text { Revised the manuscript for } \\
\text { intellectual content }\end{array}$ \\
\hline $\begin{array}{l}\text { Marta } \\
\text { Pedreño, } \\
\text { PhD }\end{array}$ & $\begin{array}{l}\text { IDIBAPS, Hospital Clínic, } \\
\text { Universitat de Barcelona, } \\
\text { Spain }\end{array}$ & $\begin{array}{l}\text { Revised the manuscript for } \\
\text { intellectual content }\end{array}$ \\
\hline $\begin{array}{l}\text { Bastien } \\
\text { Joubert, MD, } \\
\text { PhD }\end{array}$ & $\begin{array}{l}\text { IDIBAPS, Hospital Clínic, } \\
\text { Universitat de Barcelona, } \\
\text { Spain }\end{array}$ & $\begin{array}{l}\text { Revised the manuscript for } \\
\text { intellectual content }\end{array}$ \\
\hline $\begin{array}{l}\text { Silvia Ginés, } \\
\text { PhD }\end{array}$ & $\begin{array}{l}\text { IDIBAPS, Hospital Clínic, } \\
\text { and Institut de } \\
\text { Neurociències, Universitat } \\
\text { de Barcelona; and } \\
\text { CIBERNED, Madrid, Spain }\end{array}$ & $\begin{array}{l}\text { Revised the manuscript for } \\
\text { intellectual content }\end{array}$ \\
\hline $\begin{array}{l}\text { Jesús } \\
\text { Planagumà, } \\
\text { PhD }\end{array}$ & $\begin{array}{l}\text { IDIBAPS, Hospital Clínic, } \\
\text { Universitat de Barcelona, } \\
\text { Spain }\end{array}$ & $\begin{array}{l}\text { Major role in the } \\
\text { acquisition of data; } \\
\text { designed and } \\
\text { conceptualized the study; } \\
\text { and revised the manuscript } \\
\text { for intellectual content }\end{array}$ \\
\hline $\begin{array}{l}\text { Josep } \\
\text { Dalmau, } \\
\text { MD, PhD }\end{array}$ & $\begin{array}{l}\text { IDIBAPS, Hospital Clínic, } \\
\text { Universitat de Barcelona, } \\
\text { ICREA; CIBERER, Madrid, } \\
\text { Spain; and University of } \\
\text { Pennsylvania, Philadelphia }\end{array}$ & $\begin{array}{l}\text { Designed and } \\
\text { conceptualized the study } \\
\text { and drafted the } \\
\text { manuscript for intellectual } \\
\text { content }\end{array}$ \\
\hline
\end{tabular}

\section{References}

1. Dalmau J, Gleichman AJ, Hughes EG, et al. Anti-NMDA-receptor encephalitis: case series and analysis of the effects of antibodies. Lancet Neurol 2008;7:1091-1098.

2. Titulaer MJ, McCracken L, Gabilondo I, et al. Treatment and prognostic factors for long-term outcome in patients with anti-NMDA receptor encephalitis: an observational cohort study. Lancet Neurol 2013;12:157-165.

3. Irani SR, Bera K, Waters P, et al. N-methyl-D-aspartate antibody encephalitis: temporal progression of clinical and paraclinical observations in a predominantly nonparaneoplastic disorder of both sexes. Brain 2010;133:1655-1667.

4. Viaccoz A, Desestret V, Ducray F, et al. Clinical specificities of adult male patients with NMDA receptor antibodies encephalitis. Neurology 2014;82:556-563.

5. Kumar MA, Jain A, Dechant VE, et al. Anti-N-methyl-D-aspartate receptor encephalitis during pregnancy. Arch Neurol 2010;67:884-887.

6. Joubert B, Garcia-Serra A, Planaguma J, et al. Pregnancy outcomes in anti-NMDA receptor encephalitis: case series. Neurol Neuroimmunol Neuroinflamm 2020;7: e668.

7. Xiao X, Gui S, Bai P, et al. Anti-NMDA-receptor encephalitis during pregnancy: a case report and literature review. J Obstet Gynaecol Res 2017;43:768-774.

8. Hughes EG, Peng X, Gleichman AJ, et al. Cellular and synaptic mechanisms of antiNMDA receptor encephalitis. J Neurosci 2010;30:5866-5875.

9. Mikasova L, De Rossi P, Bouchet D, et al. Disrupted surface cross-talk between NMDA and Ephrin-B2 receptors in anti-NMDA encephalitis. Brain 2012;135: 1606-1621.

10. Moscato EH, Peng X, Jain A, Parsons TD, Dalmau J, Balice-Gordon RJ. Acute mechanisms underlying antibody effects in anti-N-methyl-D-aspartate receptor encephalitis. Ann Neurol 2014;76:108-119.

11. Planaguma J, Leypoldt F, Mannara F, et al. Human N-methyl D-aspartate receptor antibodies alter memory and behaviour in mice. Brain 2015;138:94-109.

12. Jurek B, Chayka M, Kreye J, et al. Human gestational N-methyl-d-aspartate receptor autoantibodies impair neonatal murine brain function. Ann Neurol 2019;86:656-670.

13. Hirasawa $\mathrm{T}$, Wada $\mathrm{H}$, Kohsaka $\mathrm{S}$, Uchino $\mathrm{S}$. Inhibition of NMDA receptors induces delayed neuronal maturation and sustained proliferation of progenitor cells during neocortical development. J Neurosci Res 2003;74:676-687. 
14. Behar TN, Scott CA, Greene CL, et al. Glutamate acting at NMDA receptors stimulates embryonic cortical neuronal migration. J Neurosci 1999;19:4449-4461.

15. Tolias KF, Bikoff JB, Burette A, et al. The Rac1-GEF Tiam1 couples the NMDA receptor to the activity-dependent development of dendritic arbors and spines. Neuron 2005;45:525-538.

16. Jagota P, Vincent A, Bhidayasiri R. Transplacental transfer of NMDA receptor antibodies in an infant with cortical dysplasia. Neurology 2014;82:1662-1663.

17. Hilderink M, Titulaer MJ, Schreurs MW, Keizer K, Bunt JE. Transient anti-NMDAR encephalitis in a newborn infant due to transplacental transmission. Neurol Neuroimmunol Neuroinflamm 2015;2:e126.

18. Planaguma J, Haselmann H, Mannara F, et al. Ephrin-B2 prevents N-methyl-Daspartate receptor antibody effects on memory and neuroplasticity. Ann Neurol 2016; 80:388-400.

19. Mannara F, Radosevic M, Planaguma J, et al. Allosteric modulation of NMDA receptors prevents the antibody effects of patients with anti-NMDAR encephalitis. Brain 2020;143:2709-2720.

20. Braniste $\mathrm{V}, \mathrm{Al}$-Asmakh $\mathrm{M}$, Kowal $\mathrm{C}$, et al. The gut microbiota influences blood-brain barrier permeability in mice. Sci Transl Med 2014;6:263ra158.

21. Ferreira TA, Blackman AV, Oyrer J, et al. Neuronal morphometry directly from bitmap images. Nat Methods 2014;11:982-984.

22. Hill JM, Lim MA, Stone MM. Developmental milestones in the newborn mouse. In: Gozes I, ed. Neuromethods. Totowa: Humana Press; 2008:131-149.

23. Weber EM, Algers B, Wurbel H, Hultgren J, Olsson IA. Influence of strain and parity on the risk of litter loss in laboratory mice. Reprod Domest Anim 2013;48:292-296.

24. Datwani A, Iwasato T, Itohara S, Erzurumlu RS. NMDA receptor-dependent pattern transfer from afferents to postsynaptic cells and dendritic differentiation in the barrel cortex. Mol Cell Neurosci 2002;21:477-492.

25. Elhardt M, Martinez L, Tejada-Simon MV. Neurochemical, behavioral and architectural changes after chronic inactivation of NMDA receptors in mice. Neurosci Lett 2010;468:166-171.

26. Paolicelli RC, Ferretti MT. Function and dysfunction of microglia during brain development: consequences for synapses and neural circuits. Front Synaptic Neurosci 2017;9:9.
27. Schafer DP, Lehrman EK, Kautzman AG, et al. Microglia sculpt postnatal neural circuits in an activity and complement-dependent manner. Neuron 2012;74:691-705.

28. Zuo Y, Yang G, Kwon E, Gan WB. Long-term sensory deprivation prevents dendritic spine loss in primary somatosensory cortex. Nature 2005;436:261-265.

29. Hoshiko M, Arnoux I, Avignone E, Yamamoto N, Audinat E. Deficiency of the microglial receptor CX3CR1 impairs postnatal functional development of thalamocortical synapses in the barrel cortex. J Neurosci 2012;32:15106-15111.

30. Paolicelli RC, Bolasco G, Pagani F, et al. Synaptic pruning by microglia is necessary for normal brain development. Science 2011;333:1456-1458.

31. Reiprich P, Kilb W, Luhmann HJ. Neonatal NMDA receptor blockade disturbs neuronal migration in rat somatosensory cortex in vivo. Cereb Cortex 2005;15: 349-358.

32. Narboux-Neme N, Angenard G, Mosienko V, et al. Postnatal growth defects in mice with constitutive depletion of central serotonin. ACS Chem Neurosci 2013;4: 171-181.

33. Bittolo T, Raminelli CA, Deiana C, et al. Pharmacological treatment with mirtazapine rescues cortical atrophy and respiratory deficits in MeCP2 null mice. Sci Rep 2016;6: 19796.

34. Single FN, Rozov A, Burnashev N, et al. Dysfunctions in mice by NMDA receptor point mutations NR1(N598Q) and NR1(N598R). J Neurosci 2000;20:2558-2566.

35. Mikulecka A, Mares P. NMDA receptor antagonists impair motor performance in immature rats. Psychopharmacology (Berl) 2002;162:364-372.

36. Malek A, Sager R, Kuhn P, Nicolaides KH, Schneider H. Evolution of maternofetal transport of immunoglobulins during human pregnancy. Am J Reprod Immunol 1996;36:248-255.

37. Simister NE, Story CM, Chen HL, Hunt JS. An IgG-transporting Fc receptor expressed in the syncytiotrophoblast of human placenta. Eur J Immunol 1996;26: $1527-1531$.

38. Dancis J, Lind J, Oratz M, Smolens J, Vara P. Placental transfer of proteins in human gestation. Am J Obstet Gynecol 1961;82:167-171.

39. Virgintino D, Robertson D, Benagiano V, et al. Immunogold cytochemistry of the blood-brain barrier glucose transporter GLUT1 and endogenous albumin in the developing human brain. Brain Res Dev Brain Res 2000;123:95-101. 


\title{
Neurology \\ Neuroimmunology \& Neuroinflammation
}

\author{
Placental transfer of NMDAR antibodies causes reversible alterations in mice \\ Anna García-Serra, Marija Radosevic, Anika Pupak, et al. \\ Neurol Neuroimmunol Neuroinflamm 2021;8; \\ DOI 10.1212/NXI.0000000000000915
}

This information is current as of November 10, 2020

\section{Updated Information \& Services}

References

Subspecialty Collections

Permissions \& Licensing

Reprints including high resolution figures, can be found at: http://nn.neurology.org/content/8/1/e915.full.html

This article cites 38 articles, 8 of which you can access for free at: http://nn.neurology.org/content/8/1/e915.full.html\#\#ref-list-1

This article, along with others on similar topics, appears in the following collection(s):

Autoimmune diseases

http://nn.neurology.org//cgi/collection/autoimmune_diseases

Developmental disorders

http://nn.neurology.org//cgi/collection/developmental_disorders

Neonatal

http://nn.neurology.org//cgi/collection/neonatal

Information about reproducing this article in parts (figures,tables) or in its entirety can be found online at:

http://nn.neurology.org/misc/about.xhtml\#permissions

Information about ordering reprints can be found online:

http://nn.neurology.org/misc/addir.xhtml\#reprintsus

Neurol Neuroimmunol Neuroinflamm is an official journal of the American Academy of Neurology.

Published since April 2014, it is an open-access, online-only, continuous publication journal. Copyright

Copyright $\odot 2020$ The Author(s). Published by Wolters Kluwer Health, Inc. on behalf of the American

Academy of Neurology.. All rights reserved. Online ISSN: 2332-7812.

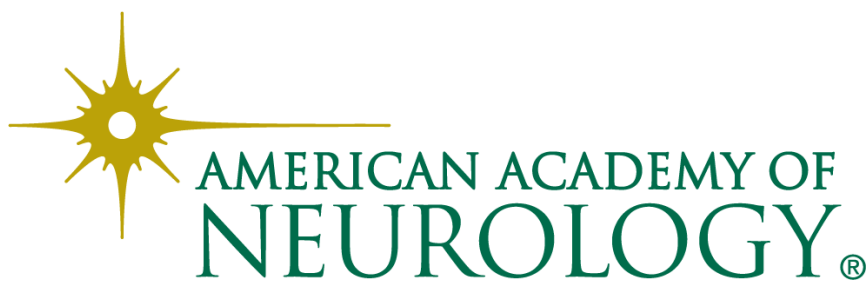

